\title{
Equal treatment of workers from third countries: the added value of the Single Permit Directive
}

\author{
Kees Groenendijk ${ }^{1}$
}

Published online: 10 December 2015

(C) The Author(s) 2015. This article is published with open access at Springerlink.com

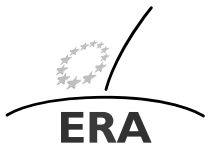

EUROPÄISCHE RECHTSAKADEMIE ACADEMY OF EUROPEAN LAW ACADEMIE DE DROIT EUROPEEN ACCADEMIA DI DIRITTO EUROPEO TRIER - TREVES - TREVIRI

\begin{abstract}
The Single Permit Directive 2011/98 provides a set of rights granting thirdcountry workers equal treatment with national workers. What is the additional value of the Directive next to the existing EU and international rules on equal treatment of those workers? After a detailed discussion of the personal scope of the equal treatment provisions and the material rights granted, the conclusion is that the Directive provides a comprehensive set of rights for almost all third-country workers admitted and employed on the basis of national or EU law, for third-country family members and students with a job, supporting their integration in the host society.
\end{abstract}

Keywords Equal treatment · Employment · Migrant worker · Third-country nationals · Single Permit

\section{Introduction}

Civil servants, politicians and practising lawyers involved in the transposition and application of the Single Permit Directive (hereafter also: the Directive or SPD) may have questioned whether the EU has competence to make binding rules on thirdcountry workers and what is the use of having this Directive. Early commentators

This article is based on a presentation given at the ERA conference "Annual Conference on European Migration Law" which took place on 7-8 May 2015.

An extended version of this paper will appear in P. Minderhoud \& T. Strik (eds.), 'The Single Permit Directive: Central Themes and Problem Issues', Nijmegen/Oisterwijk 2015 (CMR/Wolf Legal Publishers) forthcoming.

\footnotetext{
K. Groenendijk, Emeritus professor of Sociology of Law cagroenendijk@hotmail.com

1 Radboud University Nijmegen, Montessorilaan 10, 6525HR Nijmegen, Netherlands
} 
were ambivalent on the second point, speaking about 'the limited added value' of the Directive but qualifying its adoption as being 'of major importance in the field of legal migration'. ${ }^{1}$ Does the Directive bridge the gap in rights between EU workers and third-country workers and does it contribute to the integration of the workers from outside the EU? In this article we will focus on the EU's competence and the additional value of the Directive next to the existing rules on equal treatment of thirdcountry workers.

\section{EU competence and rules on access of third-country nationals to employment in Member States}

The Treaty on the functioning of the European Union (TFEU) explicitly refers to the employment of workers from countries outside the EU at two places. It provides that its rules on admission of third-country nationals 'shall not affect the right of Member States to determine volumes of admission of third-country nationals coming from third countries to their territory in order to seek work, whether employed or self-employed' (Article 79(5) TFEU). According to the second reference the Union shall as part of its social policy support and complement the activities of the Member States among others regarding 'conditions of employment for third-country nationals legally residing in Union territory' (Article 153(1)(g) TFEU). The first clause reflects the desire of some Member States to avoid EU's interference with its national policy on the admission of workers from outside the Union. The second clause reflects Members States' recognition that millions of third-country nationals are actually working in the Union and that their labour conditions influence both the labour conditions of EU workers and the integration of third-country nationals in the Member State of residence. The tension between those two political positions lies at the heart of the Single Permit Directive, it is its main raison d'être.

The competence of the Union to make binding rules on the treatment of workers from third-countries is more often implicit in treaty provisions that are broadly formulated, such as the power to legislate on 'the conditions of entry and residence, and standards on the issue by Member States of long-term visas and residence permits' and 'the rights of third-country nationals residing legally in a Member State' in Article 79(2)(a) and (b) TFEU. Both provisions are part of the Union's common immigration policy, that according to Article 79(1) TFEU, aims among others at 'fair treatment of third-country nationals residing legally in Member States'. These two clauses in Article 79(2) also provide the legal basis for the Single Permit Directive. Other implicit legal basis for EU legislation on this issue are the competence to legislate on 'standards concerning the conditions for the reception of applicants for asylum' and 'a uniform status of asylum for nationals of third countries' (Article 78(2)(a) and (f) TFEU) or the power to agree to rules on 'freedom of movement within Member States for workers from the countries and territories' in association agreements with third countries (Article 202 TFEU).

${ }^{1}$ Pascouau and McLoughlin [6]; Beduschi [1], p. 210-218. 


\section{Employment of third-country workers: three types of directives}

The competences to legislate on immigration of third-country nationals (TCN) granted by the Treaty of Amsterdam in the current Articles 78 and 79 TFEU have resulted in three types of EU instruments with legally binding rules on access to employment and rights of workers from third countries. Firstly, the rules on access to employment and employment related rights in directives on admission of other categories of third-country nationals, such as the Family Reunification Directive (2003/86), the Long-Term Residents Directive (2003/109), the Students Directive (2004/114), the Reception Conditions Directive, originally 2003/9 now 2013/33, the Qualification Directive on the status of refugees and beneficiaries of subsidiary protection, originally 2004/84 now 2011/95. ${ }^{2}$ These directives were adopted during the first five years after the Amsterdam Treaty entered into force. The asylum directives recently have been recast. All these directives cover large numbers of TCN lawfully resident in Member States.

Secondly, after the efforts of the Commission aiming at a general directive on admission for employment were blocked by Member States, in a second phase of legislative activities since 2007 a series of 'sectoral' directives were adopted on admission of certain categories of TCN workers, such as the Blue Card Directive (2009/50), the Directive on admission for seasonal employment (2014/36) and the Directive on intra-corporate transferees $(2014 / 66)$. These directives have been adopted more recently and their actual effect in Member States varies considerably. So far only Germany has issued more than 10,000 blue cards. ${ }^{3}$

The third type of relevant EU instruments do not mention employment explicitly, but implicitly open ways for third-country nationals to enter the Union and remain lawfully in a Member State for a short time and work or look for employment: the Visa Code (Regulation 810/2009), the EU Visa Regulation (539/2001) and the Regulation on local border traffic at external borders (1931/2006). These instruments may facilitate short term employment during the validity of the visa or the cross border traffic permit. ${ }^{4}$ If a long-term job is found, it is up to the employer and the worker to find a way to be granted admission and regularise the employment.

The Single Permit Directive does not belong to any of the three types defined above. The Directive does not grant a right to be admitted for employment. It provides procedural rules to be applied by Member States and on the rights acquired by those TCN who have been issued the single permit. Moreover, the Directive provides in Article 12 for equal treatment of third-country workers with nationals of the Member State where they reside, for those who have received the single permit or are allowed to work under Union law or national law. Article 12 is the longest article of the Directive. Arguably, it is its most relevant provision in practise. This contribution

\footnotetext{
${ }^{2}$ For an early overview see Groenendijk [5], p. 141-174; For the loss of Germany's battle to deny the Union the competence to legislate on access to employment of third-country nationals admitted for other purposes, see p. 144, 148-149 and 152-153.

${ }^{3}$ Eurostat, Table 'EU Blue Cards by type of decision, occupation and citizenship' (last update: 02-102014).

${ }^{4}$ See Article 3(3) of the Regulation on local border traffic and point 24 of Case C-254/11 Shomodi, ECLI:EU:C:2013:182.
} 
aims to answer the question what exactly is the additional value of this element of the SPD compared to other, already existing equal treatment clauses in EU law? In order to answer that question we will look at the personal and the material scope of Article 12 and compare that provision to similar provisions in other migration directives.

\section{The personal scope of Article 12 SPD}

The personal scope of the equal treatment clause has been subject of long debates during the negotiations. In the Commission's proposal equal treatment was granted simply to 'third-country workers'. According to the definition in Article 2(b) of the proposal that concept covered any third-country national who has been admitted to a Member State and is allowed to work legally in that Member State. ${ }^{5}$ This would have covered all lawfully employed third-country nationals. Several Member States initially preferred to restrict the personal scope of the Directive or of Article 12 in order, among other aims, to reduce the possible financial consequences of equal treatment in the field of social security. ${ }^{6}$ The Council unable to agree, asked its Legal Service whether the legal basis of the Directive was correct, considering the wide personal scope of the proposal. The Legal Service concluded that the legal basis (then Article 63(3)(a) EC Treaty) was insufficient and advised to reduce the scope of the Directive to workers holding a single permit. Following this advice, the Czech Presidency in 2009 proposed to reduce the scope of the directive and of Article 12 to Single Permit holders. This would have excluded the majority of lawfully employed third-country nationals and created yet another Union law category of third-country nationals (those holding a single permit) with its own set of rights. ${ }^{7}$ Spain under a social democratic government and on the eve of its own presidency vetoed this proposal at time unanimity was still required in the Council. After the entry into force of the Lisbon Treaty the Parliament, with new powers as co-legislator in the field of migration, proposed amendments extending the scope. ${ }^{8}$ During the Spanish Presidency in the first six months of 2010 the Council, the Parliament and the Commission agreed on a compromise extending the legal basis and the scope of both the Directive and the equal treatment. ${ }^{9}$ This compromise was codified in the final text of the Directive.

Article 12(1) SPD provides:

'Third-country workers as referred to in points (b) and (c) of Article 3(1) shall enjoy equal treatment with nationals of the Member State where they reside'.

This indicates that the personal scope of Article 12 is not identical with the personal scope of the Directive, since the latter also covers third-country national 'who apply to reside in a Member State for the purpose of work' (Article 3(1)(a) SPD). Those

\footnotetext{
${ }^{5}$ See on the concept of third-country worker also the last sentence of recital no. 19.

${ }^{6}$ Council documents 6212/08 and 5082/09.

${ }^{7}$ Council document $9617 / 09$ of 7 May 2009.

${ }^{8}$ Permosar [7], p. 150-151.

${ }^{9}$ Council documents $9192 / 10$ of 29 April 2010, 10708/10 of 8 June 2010 and 17707/10 of 11 October 2010.
} 
applicants are excluded from the scope of Article 12, as long as they have not yet been admitted for employment.

The two clauses of Article 3(1) referred to in Article 12(1) define two large categories of third-country nationals: those

'who have been admitted to a Member State for the purpose of work in accordance with Union or national law' (in point c)

and those

'who have been admitted to a Member State for purposes other than work in accordance with Union or national law, who are allowed to work and who hold a residence permit in accordance with Regulation (EC) No 1030/2002.' (in point $b$ )

For both categories it is required that the person is admitted to a Member State in accordance with Union law or national law. The Directive does not apply to undocumented workers, as is confirmed in its Recital no. $21 .{ }^{10}$ For third-country nationals admitted for purpose other than work (family members, students, researchersrefugees and beneficiaries of other forms of protections are explicitly excluded as will be explained below) there are two additional conditions: the person must be entitled to work and he must hold a residence permit in the format prescribed in Regulation 1030/2002. Their right to work can be acquired either on the basis of Union law or on national law. But it is logical that the reference 'in accordance with Union or national law' in Article 3(1)(b) applies both to the admission and to the right to work. The effet utile of the SPD and of other EU directives would be seriously reduced, if the coverage by the SPD would depend on being granted a national work permit, where those other Directives grant a right to work. In Recital no. 20 the principle is stipulated that 'All third-country nationals who are legally residing and working in Member States should enjoy at least a common set of rights based on equal treatment with the nationals of their respective host Member State, irrespective of the initial purpose of or basis for admission.' The recital explicitly refers to those admitted in accordance with the Family Reunification Directive, the Students Directive and the Researchers Directive.

The final paragraphs of Article 3 provide that Chapter II (i.e. the Articles 4-11 of the Directive) do not apply to third-country nationals allowed to work on the basis of a visa and can be excluded with regard to those with an authorisation to work for up to six months and for those admitted as students. ${ }^{11}$ A contrario, all three categories (holders of work visa, short term work permits and students) are within the personal scope of Article 12 in Chapter III of the Directive. Moreover, all three categories are covered by Article 3(1), since they have been admitted to work in accordance with Union or national law on the basis of a visa or another authorisation or they may be entitled to work under the Students Directive 2004/114. ${ }^{12}$

\footnotetext{
${ }^{10}$ For the employment rights of undocumented workers see Articles 6 and 13 of Directive 2009/52; Dewhurst [2], p. 217-238; FRA [3].

${ }^{11}$ Article 3(3) and (4) SPD.

${ }^{12}$ This is confirmed for two of the three categories in the official communication of the Council's position to the Parliament, $\operatorname{COM}(2011) 832$, p. 3 and Council document 13013/11, p. 5.
} 


\section{Exclusion from the personal scope}

The Commission in its proposal excluded nine categories of third-country nationals from the scope of the Directive and, thus, from the scope of its Article 12 as well. During the negotiations the Council and the Parliament added five more categories to the list of excluded categories in Article 3(2). In most cases the ground for exclusion was that their status is already or will be regulated by other directives. This applies to EU/EEA nationals and their family members, posted workers, seasonal workers, intra-corporate transferees, long-term residents, asylum seekers, beneficiaries of temporary protection or international protection. But that ground does not apply to au pairs, those receiving national protection and seafarers. These three categories are excluded from the scope of the Directive ${ }^{13}$ without their status being regulated in another EU directive. They will have to rely on equal treatment provisions in the relevant EU directives, in international conventions or in national law. Beneficiaries of national protection and au pairs in ten Member States can rely on the equal treatment provisions in Article 6 of ILO Convention no. 97 that applies irrespective of the nationality of the worker. Seafarers are excluded from the scope of that convention too.

The exclusion of persons 'who are long-term residents in accordance with Directive 1003/109/EC' only applies to those having acquired that status and not to their third-country national family members. This exclusion, according to Recital no. 8 is related to their 'more privileged status'. It does not pertain to their family members who have not yet obtained that status themselves. The Court in its judgment in Tahir held that the third-country national wife of a long-term resident had to comply with the five years residence requirement herself, before she could acquire the long-term resident status. ${ }^{14}$ During that period she is not excluded from the Directive and within the scope of Article 12 if she is lawfully employed.

The long negotiations on the personal scope have resulted in more complex rules in the Directive. But, after all, the personal scope is almost identical to the one proposed by the Commission: almost all third country nationals who are lawfully admitted to employment. The main categories excluded from equal treatment under the Directive are covered by equal treatment rules in other Union law instruments. Moreover, the Single Permit Directive explicitly provides that the entitlement to work may be based on Union law rather than on national law.

\section{Equal treatment of workers in other EU instruments}

Provisions granting equal treatment to third-country workers can be found in many other Union law instruments. Those provisions may supplement the equal treatment clauses in the Single Permit Directive and they may be relevant for the interpretation of those clauses in the Directive. Six types of EU instruments containing such provisions can be distinguished:

\footnotetext{
${ }^{13}$ Article 3(2)(c), (h) and (1) SPD.

${ }^{14}$ C-469/13 Tahir, ECLI:EU:C:2014:2337.
} 
- EU Charter of Fundamental Rights

- Free movement law (outside scope SPD)

- Social policy directives

- Agreements with third countries, e.g. the Association Agreement EEC-Turkey

- EU Asylum Directives (outside scope SPD)

- EU Migration Directives

Third-country workers may be covered by equal treatment provisions in the rule on free movement of Union citizens (e.g. their third-country family members) and in the EU asylum directives. Since both categories are outside the personal scope of the SPD we will not discuss their position here. Rather, we will have a short look at the relevance of each of the remaining four types of instruments for the third-country workers covered by the SPD and for the interpretation of the equal treatment clauses in the Directive.

The EU Charter of Fundamental Rights has particular relevance since it grants a range of social rights not mentioned in the European Convention on Human Rights (ECHR) as fundamental rights. Our theme is a good illustration of the additional value of the Charter. In the Charter everyone is granted the right to engage in work, but the right to look for a job and work in Article 15(2) is guaranteed for Union citizens only. Article 15(3) of the Charter stipulates:

'Nationals of third countries who are authorised to work in the territories of the Member States are entitled to working conditions equivalent to those of citizens of the Union.'

This right is granted solely to lawfully employed third-country nationals and guarantees 'equivalent' working conditions only. Article 12 of the SPD clearly goes beyond that rather vague norm in granting 'equal treatment with nationals of the Member State where they reside'. It grants national treatment to third-country workers with regard to the fields enumerated in Article 12. Two other provisions in the Charter are of relevance for third-country workers. Article 30 granting

'every worker $(\ldots)$ the right to protection against unjustified dismissal, in accordance with Union law and national laws and practises'

and Article 31 granting

'every worker $(\ldots)$ the right to working conditions which respect his or her health, safety and dignity, and to limitation of maximum working hours, to daily and weekly rest periods and to an annual period of paid leave'.

Article 31 provides additional protection since it does not have a restricting reference to Union law and national laws and practises and it explicitly refers to the dignity of the worker. This is a reminder that Article 1 of the Charter ('Human dignity is inviolable. It must be respected and protected.') is relevant for the interpretation of the Single Permit Directive as well. The Directive in Recital no. 31 makes explicit reference to the Charter and states that the Directive 'respects' the fundamental rights recognised by the Charter.

As part of its social policy the EU has adopted a series of directives on the basis of the old Article 137(2) EC Treaty, now Article 153(2) TFEU, such as Directive 
$89 / 391$ on the introduction of measures to encourage improvements in the safety and health of workers at work and Directive 2008/94 on the protection of employees in the event of the insolvency of their employer. The Court in its judgment in the Tümer case has ruled that the latter Directive also protects third-country workers, since the text and the aim of that Directive (improving living and work conditions of workers) is not restricted to Union nationals. This protection also covers undocumented workers. ${ }^{15}$ The reasoning of the Court applies to other social policy directives as well. Third-country workers also are covered by the two EU directives against discrimination, Directive 2000/43 (against racial discrimination) and Directive 2000/78 (against discrimination in employment). Both these directives have an Article 3(2) excluding distinctions on the basis of nationality or residence status from the material scope of the directive. But third-country workers are clearly within the personal scope of those two directives, as is confirmed in Recital no. 29 of the Single Permit Directive. These directives and the social policy directives supplement the protection offered to third-country workers by the Single Permit Directive.

Clauses on equal treatment of third-country workers are to be found in Association-, Partnership- and other Agreements between the EU and third countries. ${ }^{16}$ Article 13(1) SPD stipulates that this Directive

'shall apply without prejudice to more favourable provisions of Union law, including bilateral and multilateral agreements between the Union, or the Union and its Member States, on the one hand and one or more third countries on the other hand.'

A third-country worker can rely on provisions in the Directive and on equal treatment clauses in the agreements, where the latter provide wider protection or additional rights.

Between 2003 and 2014 seven directives on legal migration have been adopted. The beneficiaries of three of those directives are explicitly excluded from the personal scope of the SPD: the long-term residents in accordance with Directive 2003/109, seasonal worker and intra-corporate transferees. ${ }^{17}$ Third-country workers may derive additional rights from one or more of the other four directives: the Family Reunification Directive 2003/86, the Students Directive 2004/114, the Researchers Directive 2005/71, and the Blue Card Directive 2009/50. To what extent those other directives effectively do grant additional rights can only be established on the basis of an overview of the material scope of the equal treatment granted in Article 12 of the Single Permit Directive and a comparison with similar provisions in the other directives on legal migration. Those two subjects are dealt with in the next two paragraphs.

When reading the next paragraphs it is good to keep in mind that equal treatment and non-discrimination provisions in Union law generally have direct effect. I do

\footnotetext{
${ }^{15}$ C-311/13 Tümer, ECLI:EU:C:2014:2337.

${ }^{16} \mathrm{~A}$ list of such agreements in force at the time the Commission proposed the Single Permit Directive (2006) was included in Annex 3 to the Staff Working Document accompanying the proposal, SEC(2007)1408/3.

${ }^{17}$ Article 3(2)(d) and (e) SPD does not explicitly refer to the Directive 2014/36 on seasonal employment and Directive 2014/66 on intra-corporate transferees, since these two directives were not yet adopted in 2011.
} 
not see good grounds why the case-law developed when interpreting equal treatment provisions protecting EU workers would not apply also to Union law equal treatment provisions protecting third-country workers. After all Recital no. 2 reminds us that the Single Permit Directive is one of the directives the European Council in 1999 in Tampere asked for with the aim to ensure fair treatment of third-country nationals who are legally residing in the territory of the Member States and to grant them rights and obligations comparable to those of citizens of the Union as part of a vigorous integration policy.

\section{The material scope of Article 12: eight areas}

In Article 12(1) equal treatment with nationals of the Member State where the thirdcountry worker resides is granted with regard to eight areas. With regard to four of those areas (labour conditions, trade union rights, recognition of diplomas and advice of employment offices) the text of the Directive is identical to the Commission's proposal. The other four areas (education, social security, tax advantages and access to goods and services) were subject of prolonged negotiations in the Council and between Council and Parliament that in the end reduced the scope of the equal treatment, mostly because Member States wanted to avoid possible additional costs. ${ }^{18}$ Several efforts of Member States aiming at a further reduction of the scope were blocked by the Parliament, especially by its Employment Commission. ${ }^{19}$ An academic observer noted the almost complete absence of the frame of 'integration' in the negations on the Single Permit Directive and the Blue Card Directive. 'Whereas migrant integration had been an ubiquitous topic during the first phase of policies on the rights of third-country nationals - first as a frame to justify the expansion of rights to third-country nationals, and later as a frame that enabled Member States to impose new conditions on the acquisition of these same rights-it simply did not play a role in the discussion' on the proposals for the two directives that were introduced by the Commission on the same day in $2007 .^{20}$

For the definition of the different areas the Commission in its proposal, apparently, used similar equal treatment clauses in other legal migration directives as a model. For several areas the wording in the Single Permit Directive is identical with the similar clause in the Researchers Directive. The restrictions were either introduced in the definitions in Article 12(1) or by allowing Member State additional room to restrict the equal treatment in paragraph 2. The length of Article 12(2) in the Directive is twice the length in the Commission's proposal. With regard to several areas further specifications are to be found in the recitals of the Directive.

The clause on labour conditions, health and security in Article 12(1)(a), according to Recital no. 22, also covers 'working time and leave taking into account collective agreements in force'. As explained above the Articles 30 and 31 of the Charter are relevant for the interpretation of this clause.

\footnotetext{
${ }^{18}$ Brinkmann [4], 'Opinion of Germany on the Single Permit Proposal', EJML 2012, p. 351-366 and Beduschi [1].

${ }^{19}$ Pascouau and McLoughlin [6].

${ }^{20}$ Permoser [4], p. 153-154.
} 
With regard to the recognition of professional qualifications mentioned in Article 12(1)(d) Recital no. 23 specifies that Member States should recognise professional qualifications acquired by a third-country national in another Member State in the same way as those of citizens of the Union and should take into account qualifications acquired in a third country in accordance with Directive 2005/36/EC on the recognition of professional qualifications. In the same recital it is affirmed that the equal treatment regarding recognition of diplomas and qualifications is 'without prejudice to the competence of Member States to admit such third-country workers to their labour market.' Recognition of qualifications does not imply a right to a single permit.

The equal treatment in the field of education can be restricted by the freedom allowed to Member States in Article 12(2)(a) to exclude third-country workers who have not yet been employed and students, exclude study grants and loans and impose requirements regarding language proficiency and payment of tuition fees. According to Recital no. 27, equal treatment with respect to vocational training does not cover measures financed under social security schemes.

Equal treatment with regard to social security covers all branches defined in Regulation 883/2004 for EU workers. But Member States may restrict the equal treatment for those who are unemployed or have been employed for less than six months and not pay family benefits to those admitted for less than six months, for the purpose of study or for work on the basis of a visa. ${ }^{21}$ The prolonged battle between the Parliament's Employment and Social Affairs Committee and the Council on the portability of benefits in relation to old age, invalidity and death resulted in a compromise in Article 12(4): export under the same conditions and at the same rates as the nationals of the Member State concerned when they move to a third country. ${ }^{22}$ Member States can only reduce those benefits for third-country workers, if they reduce those benefits for their own nationals as well. I am not in a position to judge whether all these exceptions are in conformity with the equal treatment regarding social security provided for in Article 6(1)(b) of the (ILO) Migration for Employment Convention no. 97 and the Equality of Treatment (Social Security) Convention no. 118.

With regard to tax benefits the equal treatment is restricted to workers who are for tax purposes deemed to be resident in the Member State and by allowing Member States to apply it only to cases where the registered residence of the family members of the worker for whom (s)he claims the benefits lies in the Member State. ${ }^{23}$

The equal treatment with regard to access to goods and service is restricted by adding in Article 12(1) $(\mathrm{g})$ a reference to national law and to the 'freedom of contract in accordance with Union and national law'. Moreover, Article 12(2)(d) allows Member States to exclude unemployed third-country workers and 'access housing' from the equal treatment.

Article 6 of ILO Convention no. 97 also grants equal treatment with respect to 'legal proceedings relating to the matters referred to in this Convention.' A similar

\footnotetext{
${ }^{21}$ Article 12(2)(b) SPD.

${ }^{22}$ Brinkmann [4]; Pascouau and McLoughlin [6] on the different perspectives of the two committees of the Parliament, the LIBE committee and the Employment and Social Affairs committee, the first having more the migration management perspective and the latter focusing more on social rights and integration.

${ }^{23}$ Article 12(1)(f) and Article 12(2)(c) SPD.
} 
provision, granting equal treatment regarding equal access to courts and legal aid and granting workers dispensation from a provision of security for costs before an action is brought (cautio judicatum solvi) did not appear in the Commission's proposal. It was not included in the final version of the Directive. But Article 47(1) of the EU Charter of Fundamental Rights grants to "everyone whose rights and freedoms guaranteed by the law of the Union are violated [...] the right to an effective remedy before a tribunal in compliance with the conditions laid down in this Article'. Moreover, Article 47(3) provides that 'legal aid shall be made available to those who lack sufficient resources in so far as such aid is necessary to ensure effective access to justice.' This guarantee also covers the rights granted in Article 12 SPD. The Court has held that 'legal aid' in Article 47(3) may cover both assistance by a lawyer and dispensation from payment of the costs of proceedings, including dispensation from provision of security for costs before an action is brought. ${ }^{24}$ But Article 47(3) does not explicitly provide for full equal treatment in legal aid for third-country workers claiming their rights under the Single Permit Directive.

\section{Freedom to restrict equal treatment is not unlimited}

In Article 12 SPD at four places explicit reference is made to national law or procedures and in the second paragraph a series of options to restrict equal treatment is listed. The freedom to restrict equal treatment granted to Member States in those clauses is not unlimited. That freedom is limited by Member States' obligations under Human Rights instruments ${ }^{25}$ and ILO conventions. In Kamberaj, its first judgment regarding the equal treatment clause in Article 11 of the Long-Term Resident Directive, the Court reminded that Union law limits the freedom to restrict the equal treatment in three ways. Firstly, a reference to national law does not mean that a Member States may undermine the effectiveness of the Directive when applying the principle of equal treatment. Secondly, those restrictions are exceptions to the equal treatment rule and, thus, must be interpreted strictly. Thirdly, the concepts in those clauses have to be interpreted in conformity with the relevant provisions of the Charter. ${ }^{26}$ Those three considerations will apply to the restrictions in the equal treatment provisions of Article 12 Single Permit Directive as well. Recital no. 31 explicitly states that the Directive respects the fundamental rights recognised in the Charter. Article 13(2) allows Member States to adopt or maintain provisions that are more favourable to the persons whom it applies to. This confirms that the Directive de facto sets minimum standards, as was stated by the Commission with respect to Article 12 in the explanation to its proposal. ${ }^{27}$

\footnotetext{
${ }^{24}$ Case C-279/09 DEB, ECLI:EU:C:2010:811, points 47-48 held that legal aid may cover both assistance by a lawyer and dispensation from payment of the costs of proceedings. For previous judgments regarding dispensation of cautio judicatum solvi; see Case C-43/95 Data Delecta en Forsberg, ECLI:EU:C:1996:357; Case C-323/95 Hayes, ECLI:EU:C:1997:169 and Case C-122/96 Saldanha, ECLI:EU:C:1997:458.

${ }^{25}$ Beduschi [1], p. 224.

${ }^{26}$ Case C-571/10 Kamberaj, ECLI:EU:C:2014:233, points 78, 86, 79-81 and 92.

${ }^{27} \mathrm{COM}(2007) 638$, p. 10.
} 
Finally, Member States added a clause that the right to equal treatment does not create any residence rights. This provision in Article 13(3) SPD was explicitly introduced to prevent that the Court of Justice would extend its case law in El Yassini and Gattoussi on the equal treatment provisions in the Association Agreements with Morocco and Tunisia to third-country workers generally. ${ }^{28}$ But this clause is yet another confirmation that Article 12 indeed grants rights to those workers.

\section{Comparison with other directives on legal migration}

Detailed equal treatment provisions are to be found in four legal migration directives. How does Article 12 SPD compare with the similar provisions in those four directives? The equal treatment provided for in Article 14 of the Family Reunification Directive is clearly more limited, since it covers only the access to (self-)employment, education and vocational training and provides only for equal treatment with the sponsor, not equal treatment with the nationals of the Member State. The equal treatment clause in Article 11 of the Long-Term Residents Directive is the most extensive one. In comparison with Article 12 SPD, that Directive grants more rights to longterm residents, since it also covers equal treatment with regard to social assistance, study grants and housing. This wider scope is justified by the fact that this privileged status can only be obtained by third-country nationals after five years of lawful residence in a Member State. Apparently, the Commission, when drafting its proposal for Article 12 SPD in 2007, used the existing equal treatment provisions in the 2003 Long-Term Residents Directive and the 2005 Researchers Directive as a model. ${ }^{29}$ The material scope of the equal treatment clauses in Article 12 SPD is fairly similar to the scope of the Researchers Directive. The many restrictions included in Article 12 SPD are absent in the Researchers Directive. That Directive does not cover access to education, apparently, because researches are expected to teach rather than receive education. ${ }^{30}$ The scope of the equal treatment provided for in Article 14 of the Blue Card Directive, adopted in 2009, is wider than Article 12 SPD, mainly because there are no restrictions during the first six months of employment or during unemployment and less limitation on access to accommodation. Surprisingly, there is no clause on tax advantages in Article 14 Blue Card Directive and the clause on export of statutory pension rights covers only old age pensions, whilst the similar clause in Article 12(4) SPD covers pension related to invalidity and death as well. Since highly qualified workers are not excluded from the personal scope of the Single Permit Directive, they can rely on these improvements in that younger Directive. ${ }^{31}$ Other provisions in the Blue Card Directive grant highly qualified workers privileges with respect to family reunification, acquisition of the long-term resident status and mobility within the EU, issues that do not appear in the Single Permit Directive. The

\footnotetext{
${ }^{28}$ Council documents 7338/07 of 13 March 2007, 6216/08 of 5 March 2008, 10807/08 of 2 July 2008 and $12054 / 08$ of 22 July 2008 , p. 9.

${ }^{29} \mathrm{COM}(2007) 638$, p. 3.

${ }^{30}$ Cfr. Article 11 of Directive 2005/71.

${ }^{31}$ I am grateful to Samah Ousmane of the Universite de Fribourg for drawing my attention to this point.
} 
material scope of the equal treatment granted to almost all third-country workers in the Single Permit Directive is more restricted but not that different from the scope of the equal treatment granted by Union law to researchers and highly qualified workers from third-countries. The Long-Term Residents Directive is at the top end of the spectrum. The Family Reunification Directive is at the bottom, but it's very limited equal treatment clause is now supplemented by the Single Permit Directive.

The Students Directive 2004/114 does not contain an equal treatment clause. The Commission in its 2013 proposal for a recast, merging that Directive with the Researchers Directive, included an equal treatment clause that explicitly refers to the Single Permit Directive. In December 2014 Member States reached agreement in the Council on a mandate for the negotiations with the Parliament on that proposal. Article 21 of that text explicitly refers to Article 12 SPD and extends the scope of that Article of the SPD to lawfully employed students and researchers. Certain elements of the equal treatment in Article 12 are extended to unremunerated trainees and volunteers. ${ }^{32}$

\section{Conclusions}

In 2013 a total of 2.4 million first residence permits were issued in the EU-28, of which $28 \%$ for family reasons, $23 \%$ for employment reasons and $20 \%$ for educational reasons. ${ }^{33}$ Thus, half of all first permits were issued to family migrants and students. Considering the limited scope of the equal treatment provisions in the Family Reunification Directive and the absence of such provision in the current Students Directive, Article 12 SPD provides an important set of rights for third-country family members and students who find a job and are employed. Moreover, Article 12 SPD provides the same set of rights for almost all third-country workers (almost one quarter among the first admissions in 2013) admitted and employed on the basis of national law, irrespective whether they work on the basis of a residence permit or a visa and work permit, and irrespective of the duration of their lawful employment. Once the pending merger of the Students Directive and the Researchers Directive has been adopted Article 12 SPD will apply to third-country students and researchers. The Commission's aim to have a horizontal directive creating one set of rights for the majority of third-country workers in the EU will then be realised to a large extend.

Have the aims set by the Tampere European Council, repeated in the second recital of the Directive - to ensure fair treatment of legally resident third-country nationals in the Member States and to grant them rights and obligations comparable to those of Union citizens - actually been met? The rights granted to third-country workers in Article 12 SPD clearly are not comparable to the rights of EU workers. Those who expected full equal treatment of EU and third-country workers are rightly disappointed. But were their expectations realistic? The rights of third-country workers are also below the rights granted to long-term residents after five years of lawful residence under

\footnotetext{
${ }^{32}$ Council document 16512/14, p. 94.

${ }^{33}$ Eurostat News Release STAT/14/159 of 22 October 2014. Refugees and beneficiaries of other forms of protection are included in the $29 \%$ third-country nationals admitted for 'other reasons'.
} 
Directive 2003/109 and far from equal to the rights of EU workers. But does the set of rights in Article 12 SPD ensure 'fair treatment', the other even less concrete aim set in Tampere? The Directive grants almost full equal treatment as concerns directly work related rights (employment conditions, trade union rights and certain branches of included social security), but not much beyond that important core set of rights. It would be unrealistic to expect Member States to grant full equal treatment as Union citizens, including mobility within the Union to third-country workers immediately after their admission in a Member State. But is it fair to require third-country workers to pay full taxes and social contributions and, even if they have worked for more than five years in a Member State but do not yet qualify for the long-term resident permit, exclude them and their children from equal access to housing, study grants and social assistance? Does that contribute to the 'vigorous integration policy' our political leaders had in mind in Tampere. The set of rights in Article 12 SPD at several points (access to housing, legal remedies and possibly social security rights) does not meet the equal treatment standard set by the ILO in its 1949 Migrant Workers Convention no. 97. Six Member States ratified that convention during the 1950s with the intention to support and protect their citizens who migrated to Australia, New Zealand, Canada and other countries outside Europe. For non-EU workers in the sixteen Member States that are bound by the Directive (Denmark, Ireland and the UK are not bound) but have not ratified the ILO convention, Article 12 of the Directive provides for national treatment in a series of field irrespective of the nationality of the worker. This is a clear indication of the added value of the Directive.

The Single Permit Directive sets a minimum standard for the treatment of almost all third-country workers in the 25 Member States bound by the Directive. For the main categories of third-country nationals excluded from the personal scope of the Directive (posted workers, asylum seekers, refugees and beneficiaries of subsidiary or protection, seasonal workers, intra-corporate transferees, family members of EU nationals) other instruments provide specific rights or equal treatment, at a level above the level of the Single Permit Directive. Only for seasonal workers and asylum seekers the level in Union law is lower. But, all those third-country workers are protected by Union law against a regression of the national legislation or practise below the level granted in the Directive. Only third-country nationals admitted as self-employed workers, seafarers or au pairs have to fall back on the minimum protection granted to everyone in the EU Charter or in other international instruments. Undocumented third-country workers are outside the scope of the Single Permit Directive, but they are not without protection in Union law. As regards their social rights, undocumented third-country workers are entitled to the protection of the EU Social Policy directives, as appeared from the Tümer judgment, they are entitled to back payment of their salary by their employer under the Employer Sanctions Directive 2009/52 and they are within the personal scope of the Directive against racial discrimination (Directive 2000/43) and employment discrimination (Directive 2000/78). In each of those situations they are also entitled to the protection the EU Charter of Fundamental Rights grants to everyone, which extends also to persons without a residence right.

It is now up to the Member States to transpose the Directive, actually grant equal treatment in their national law and control the compliance by employers and other third parties with the equal treatment provisions of the Directive. When confronted 
with the need to transpose the equal treatment provisions in the Long-Term Residents Directive, in many Member States the reaction was: 'We have already a general equal treatment legislation in place and that is sufficient.' Only a few Member States at the time of transposition systematically checked whether their national legislation regarding employment, education, social security and the other areas covered by the equal treatment provisions in Article 11 of Directive 2003/109 did really comply with the requirements of the new Directive. I would be surprised if the reaction regarding Article 12 SPD was very different. Once national authorities, employers, trade unions, lawyers and judges start to take the comprehensive set of rights for third-country workers in the Single Permit Directive seriously, it may well become an important instrument supporting their integration in the host society. ${ }^{34}$

Open Access This article is distributed under the terms of the Creative Commons Attribution 4.0 International License (http://creativecommons.org/licenses/by/4.0/), which permits unrestricted use, distribution, and reproduction in any medium, provided you give appropriate credit to the original author(s) and the source, provide a link to the Creative Commons license, and indicate if changes were made.

\section{References}

1. Beduschi, A.: An empty shell? The protection of social rights of third-country workers in the EU after the single permit directive. Eur. J. Migr. Law 17, 210-218 (2015)

2. Dewhurst, E.: The right of irregular immigrants to pay: the spectrum of protection in international, regional and national legal systems. In: Costello, C., Freedland, M. (eds.) Migrants at Work: Immigration and Vulnerability in Labour Law. Oxford University Press, Oxford (2014)

3. EU Agency for Fundamental Rights: Fundamental rights of migrants in an irregular situation in the European Union, Vienna (2011). Available at: http://fra.europa.eu/sites/default/files/fra_uploads/1827FRA_2011_Migrants_in_an_irregular_situation_EN.pdf

4. Brinkmann, G.: Opinion of Germany on the single permit proposal. Eur. J. Migr. Law 14, 351-366 (2012)

5. Groenendijk, K.: Access of third-country nationals to employment under the new EC migration law. In: Julien-Laferrière, F., Labayle, H., Edström, O. (eds.) The European Immigration and Asylum Policy: Critical Assessment Five Years After the Amsterdam Treaty, Bruylant, Brussels (2005)

6. Pascouau, Y., McLoughlin, S.: EU Single Permit Directive: a small step forward in EU migration policy. ECP Policy 2012, EPC Policy Brief, of 24 January 2012, Brussels, available at: http://www. epc.eu/documents/uploads/pub_1398_eu_single_permit_directive.pdf

7. Permosar, J.S.: Redefining membership: European Union policy on the rights of third country nationals. Dissertation, University of Vienna, Vienna (2010)

${ }^{34}$ Beduschi [1], p. 236. 